\title{
Attila Barta \\ THE WAY TO A MORE INTEGRATED TERRITORIAL STATE ADMINISTRATION. THE AIMS AND CAUSES BEHIND THE RENEWAL OF HUNGARIAN MID-LEVEL STATE ADMINISTRATION ${ }^{1}$
}

\section{Uton egy integráltabb területi államigazgatás felé. A magyar középszintü államigazgatás megújításának céljai és indokai}

Dr. Attila Barta PhD, Assistant Professor of Law, University of Debrecen, Faculty of Law, Department of Administrative Law, barta.attila@law.unideb.hu

This study focuses primarily on the territorial bodies of mid-level state administration. Hungarian territorial state administration has been under constant transformation since 1989-1990. As other studies have already researched the key steps of this transformation extensively, this paper focuses solely on the major developments of the 2016/2017 calendar years (primarily due to the manuscript deadline). The study is mostly based on the analysis of the relevant Hungarian legislation, but also contains an international outlook. In summary, the paper concludes that in recent years the number of Hungarian territorial administrative organisations have been greatly reduced, the importance of the capital and county government offices have been greatly increased, the system of the district-level offices have been differentiated, and the customer relationship solutions have seen a notable renewal. The aforesaid conclusions will also offer a system-level interpretation of this Neo-Weberian Hungarian transformation.

KEYWORDS:

District Offices, Government Windows, Hungarian County (and Capital) Government Offices, public administration, territorial state administration

This work was created under the priority project KÖFOP-2.1.2-VEKOP-15-2016-00001 titled „Public Service Development Establishing Good Governance” in cooperation with the National University of Public Service and the 'DE-ÁJK Governance Resource Management Research Group' of the University of Debrecen. For the description of the underlying concepts, see: HORVÁtH 2016, 25-37. 
A tanulmány a közigazgatás középszintü intézményei közül alapvetöen a területi államigazgatási szervekkel foglalkozik. A területi államigazgatás Magyarországon 1989-1990 óta folyamatos átalakulásban van. Tekintettel arra, hogy ennek a folyamatnak a lépéseit más írások már ismertették, a munka alapvetö célja - a kézirat lezárásának idöpontjára tekintettel - a 2016-2017-es fejlesztések feldolgozása volt. A munka elsősorban a releváns magyar joganyag elemzéséböl indult $k i$, de nemzetközi kitekintést is tartalmaz. A tanulmány megállapítja, hogy az elmúlt években a magyar területi államigazgatási szervek száma jelentösen csökkent, a fövárosi, megyei kormányhivatalok szerepe nőtt, a járási (kerületi) hivatalok rendszere differenciálódott, az ügyfélkapcsolati megoldások pedig jelentösen megújultak. A következtetések kitérnek a neo-weberi elemeket is felmutató magyar átalakitások rendszerszintü értelmezésére.

\section{KulcsszavaK:}

járási hivatalok, kormányablakok, közigazgatás, területi államigazgatás, területi kormányhivatalok 


\section{OVERVIEW}

This study investigates the so-called territorial (or deconcentrated) organisations of state administration. As we will see, these organisations compose the mid-level (or territorial) units of government public administration, both in Hungary and in other European countries. In most countries, the middle/territorial (or meso) level of public administration consists of multiple agents. This means the following:

- They exist alongside territorial state administration.

- Law enforcement administration also has deconcentrated bodies (such as police departments).

- Local administration may also utilise territorial solutions (organised either on a regional, county or district-level).

- In certain special fields (such as regional development or tourism) organisations with special legal status could also exist.

Due to all of these, it is desirable to separate the organisations in the title-role of this study from the organisations mentioned in the above list. Their most important properties are the following:

- Territorial state administration organisations operate as an office, and are led by a single person.

- They are parts of the state administration hierarchy, and operate as branch offices of a central organisation.

- They are usually responsible for handling specialised duties that require unified administration on a country-level (such as treasury matters, taxation or epidemics).

- They usually handle duties that grant executive powers (such as performing official controls).

- Finally, the responsibilities of such organisations may deviate from general geographical jurisdiction (e.g. they may pertain to drainage areas, mining locations or nature reserve areas instead).

Although the different time periods and country-specific adaptations result in obvious differences, the properties listed above still readily show the most important common characteristics of these organisations. Considering the fact that territorial administrative duties are handled by multiple organisations, it is recommended to differentiate those. The most common type of differentiation classifies these organisations into general and specialised deconcentrated administrative bodies.

In Hungary, most of the territorial administrative bodies are specialised organisations (see Chapter II, Point 5 of this paper for their in-depth description). This means that they are handling responsibilities related to a specific administrative duty (such as water conservancy, asylum, or public education). General deconcentrated administrative bodies mainly exist for two reasons. Firstly, because certain responsibilities cannot be covered with specialised organisations (such as practicing the legal control of municipalities, or 
coordinating other territorial administrative organisations). Secondly, because government administration should be represented by a specific organisation on a territorial level.

\section{THE MAIN COMPONENTS OF RENEWING HUNGARIAN TERRITORIAL STATE ADMINISTRATION}

Hungarian territorial state administration has been constantly transforming since 19891990. As some major steps of this evolution have already been covered elsewhere, ${ }^{2}$ this study is focusing only on the developments that have occurred in 2016/2017 and have affected the operation of territorial state administration in $2018 .^{3}$ This chapter and its subchapters therefore cover the following topics:

- Developments of the general deconcentrated administrative bodies, the County (or Capital) Government Offices.

- The functions and tasks of the District Offices, which are the branch offices of the Capital and County Government Offices.

- The one-stop-shops (Government Windows) of the District Offices.

- A short summary of some additional solutions supporting the work of the Government Windows.

- A description of middle-level specialised territorial state administration organisations.

- A summary of the miscellaneous territorial organisations that operated in 20162017-2018 alongside the deconcentrated state administration bodies in Hungary.

\subsection{Developments of County and Capital Government Offices}

The post-transformation governments of Hungary always considered the renewal of public administration one of their top priorities. This renewal would also include the rationalisation of territorial state administration and the creation of a general-duty deconcentrated organisation. These efforts were not always successful, but megacrises like the financial crisis of 2008 still fuelled the aspirations, as such challenges cast light upon the fact that government roles and executive power must be re-evaluated, and that public institutions must be reinforced. ${ }^{4}$ As part of these aspirations, 1 January 2011 saw the

2 See the following English works in chronological order for more information: BARTA 2012, 75-84.; PATYIRiXer 2014, 304-319.; BARTA 2017, 27-42.

3 Due to the manuscript deadline, this paper studies the data available up to 2018 and the developments in territorial administration completed until 2018. Therefore, this essay does not contain any conclusions beyond that year. Hungarian territorial state administration has been seeing major developments throughout 2019 and 2020 as well - due to constraints in length and the scope of this paper, these developments will be investigated in further studies.

4 Available: www.keepeek.com/Digital-Asset-Management/oecd/governance/government-at-a-glance-2017 gov_glance-2017-en\#page1 (Downloaded: 10. 07. 2018.) 
inception of the County and Capital Government Offices (hereafter GOs). The GOs were meant to be the territorial offices of the government - in the following years, their duties, responsibilities and sphere of authority were expanded, while their structure was finalised.

Late 2016 and early 2017 saw an extensive reform. Initiated from the centre of the public administration system, it was applied with a domino effect, affecting all agents of state administration right until the district level. The goal of the reform was to establish a simpler and more cost-effective system by delegating special duties to the GOs and their branches that were previously managed on a higher level of administration.

The reassignment of responsibilities was carried out constantly by several means. This study covers only the solutions that changed the duties of the GOs and their districts. Such changes were numerous: of the approximately 500 duties that were re-evaluated, around half of those were delegated to the GOs. Such responsibilities and the means of delegation included the following:

- Some specialised duties were handed over to a single GO to manage for the whole country. For example, the duties of the former Institute of Geodesy, Cartography and Remote Sensing are managed by the Capital GO of Budapest.

- Certain duties are handled by some GOs with regional competence in multiple counties. These include some type of rehabilitation cases, for example.

- In some cases, a specific duty has been assigned to all GOs (such as the authorisation of aerial mosquito spraying).

- Around 50 administrative procedures were delegated to district-level administration from the central level (such as revising the expert report required for requesting increased family allowance).

As a result of the above tendencies, the 20 GOs in Hungary are substantially differentiated. In addition, due to the responsibilities and authorities migrating to the middle level, task allocation between the GOs and their districts has also changed. Following the review of approximately 1000 public proceedings addressed to the GOs, about $80 \%$ of those were transferred to the District Offices, effective 1 January 2017. As described in subsequent parts of this study, similar to the county-level, this also resulted in differentiation and the creation of offices with different competencies on the district level as well. It is also important to mention that the transfer of duties also induced the transfer of their respective public servants, resulting in a change in staff numbers: while in 2015 the number of public servants working in the county and district level administration was roughly the same, most of the manpower later shifted toward the district level, due to the vertical re-assignment of tasks. ${ }^{5}$

For example, the GO of Hajdú-Bihar County had a staff of 1857 in 2015, of which 913 worked on the county level, and 944 worked on the district level. As a result of the transformations, the staff number rose to 1939, with the number of public servants working for the county GO decreased to 568, but the number of administrators working for the districts increased to 1371. In 2017, the overall number of employees did not change, only the internal distribution: 566 servants worked on the county level, and 1373 on the district level. 
Because of the changes in territorial state administration, legislation managed to rationalise property apportioning, energy usage and software usage, and could also reduce postal fees. However, besides these developments, numerous pivotal procedural, infrastructural, IT and human achievements also took place:

$-75 \%$ of the on-going cases reached decision-making status within 8 days. This ratio is not expected to decline once the new procedural act (governing further cases) takes effect.

- Electronic developments (such as the effort to make GOs rely solely on electronic means in their internal ways of working) and their associated trainings are expected to make public administration more agile and cost-effective.

- The rationalisation and modernisation of the properties serving as premises for GOs ensure economical facility maintenance.

- The modification of regulations applicable to GO staff aims to improve the motivation of the personnel affected by the constant organisational and operational reforms with financial means.

\subsection{The functions and tasks of District Offices}

The district system is a historical low-mid level segment of Hungarian state administration looking back to a long tradition. The institution was established in the $13^{\text {th }}$ century, and - with a varying degree of extent and responsibilities - existed until 1983. Following the liquidation of the district system, there was no standard low-mid level organisation within Hungarian state administration for nearly three decades. This started to become a pressing issue during the 1990s, as public administration saw an increase in the responsibilities following the democratic transformation of 1989/90, that required an administrative framework above the municipalities, but below the county level of state administration. The notion of "rehabilitation" of the districts resurfaced mostly due to two factors: firstly, because of the re-evaluation of state-side and municipal administrative duties; and secondly, to eliminate the unwarranted structural and operational differences experienced in the lowto-middle level of public administration.

Today's district system was originally based on the idea that legislation would delegate all state administration duties from the municipalities to the districts. However, it soon became apparent that this cannot be achieved. At the same time, the establishment of the 175 county and 23 capital District Offices (hereafter DOs) on 1 January 2013 indicated that there may be responsibilities later down the line that legislation aims to reassign to the lowest level of state administration (that is, the districts). It was also likely that these responsibilities would be re-delegated not from the municipalities - as was the case at the end of 2016 and early 2017 - but from higher levels of state administration.

The proceedings described above eventually resulted in the reinforcement of the district system: starting from 1 January 2017, out of the 1106 responsibilities of the GOs, 914 have been reassigned to the DOs, along with 36 additional activities from other central 
administrative agencies. The lowest level of state administration ${ }^{6}$ saw a huge increase in responsibilities.

However, along with the increased number of duties came differentiation: the number and types of cases available for management started to vary among the districts. Therefore, the large-scale reassignment also resulted in the following deviations in that time:

- All DOs became eligible to manage consumer protection, ${ }^{7}$ public education and agricultural matters.

- Certain DOs received an "advanced" status, covering multiple districts in matters concerning land registry, building, general health or animal welfare, among others.

- Specific cases can only be managed by county seat DOs. These include matters concerning family allowance ${ }^{9}$ or state aid for housing, and responsibilities related to territorial environmental protection, or nature conservation.

As mentioned earlier, transformation also resulted in the re-assignment of the personnel: most of the civil servants have been transferred from the county level to the district level. In 2017, the 20 GOs and the 197 DOs (their numbers reduced in the interim ${ }^{10}$ ) employed roughly 36,000 public servants, approximately 11,000 of them working on the capital/ county level, and 25,000 employed in the low-mid level of public administration. ${ }^{11}$

Based on the assessment above, it is clear that the district system is constantly evolving, with its responsibilities still being fine-tuned. And in all probability, this is expected to continue in the coming years. ${ }^{12}$

\section{3. “One-stop-shops" in the reformed territorial state administration system}

The concept of single-window administration (that is, the implementation of one-stop-shops) is not a novelty in Hungary: the intention emerged two years after the country joined the

Available: http://jarasinfo.gov.hu/jarasokrol (Downloaded: 05. 07. 2018.)

Major and more complex consumer protection procedures were, however, assigned to county seat District Offices.

8 Such DOs typically serve two or three districts. However, some DOs have an even larger jurisdiction: for example, the District Office of Balmazújváros handles the general health matters of four districts.

$9 \quad$ Since July 2017, family allowance duties and authorities are handled not just by county seat DOs, but 13 additional DOs as well - though the latter group of DOs handle only matters originating from their own local districts.

10 The number of districts was reduced by one in the meantime, as the District of Polgárd ceased to exist on 31 December 2014.

11 The change in the number of public servants is well visualised in the table available at the following URL: http:// kozepszintuallamig.blogspot.hu/2017/05/tisztviselok-letszama.html (Downloaded: 07. 07. 2018.)

12 Following the manuscript deadline, the District Office system has seen major changes at the end of 2019 and the beginning of 2020. Due to constraints in length, the scope of this paper, and the complexity of these changes, the recent developments will be investigated in further studies. However, it is still worth mentioning here that with these changes, legislation aims to move certain duties back to the county level, and in the meantime, to unify the responsibilities of the District Offices. 
European Union. This is due to Directive 2006/123/EC on the services in the internal market, which specifically defined the conditions of single-window administration to streamline public administration. ${ }^{13}$ According to the Directive, ${ }^{14}$ the simplification of administration should warrant a single point of contact for each service provider, where all procedures can be arranged, and all formal requirements can be fulfilled. Due to the antecedents, it is not surprising that the key component of the transformation in progress since 2010 is the streamlining of official administration and customer service activities. The fundaments of this effort were 29 "first-generation" Government Windows (hereafter GWs), founded on the groundwork of the capital and county GOs back in 2011.

The continuous expansion of the GW-network is readily reflected by the following milestones:

- In early 2011, GWs served 29 types of cases. Starting from 15 October, that number rose to 61 .

- From 2013, legislation transferred customer services from the capital/county level to the district level (resulting in the "second-generation" GWs).

- In 2014, integrated customer service points handled 265 types of cases. GW public servants handled approximately 5,500 cases per week.

- By the end of 2015, the 245 district client points of the country managed 509 types of cases.

- At the end of 2016, there were roughly $260 \mathrm{GWs,} \mathrm{while} \mathrm{the} \mathrm{types} \mathrm{of} \mathrm{cases} \mathrm{handled} \mathrm{by}$ Government Windows also increased substantially, covering approximately 1,500 case types. The number of cases actually handled in GWs was close to 13 million.

- In 2017, there were 266 complex customer service points in operation in Hungary, handling 14 million cases for 12 million clients, spanning 1,558 types of cases. ${ }^{15}$

At the beginning of 2018, the Government Window network consisted of 280 offices, and citizens could handle more than 2,000 types of cases at them. These cases cover multiple types, but can be classified as follows:

- Immediately administered (i.e. replacing Vehicle Registration Certificate).

- Administered within the GW's own sphere of authority (i.e. handing out or replacing personal passports).

- Complementary services (i.e. Client Gate registration).

- Ex officio matters (i.e. official control of self-employed citizens).

- Providing information and orientation (i.e. on requesting child-care allowance).

VesZPRÉMi 2015, 176-177.

Paragraph (48).

This is two-thirds of the total number of clients served by territorial state administration. For additional interesting statistical data, see the data collection of OSAP 1229: www.kormany.hu/hu/dok?page $=1$ \&source $=7$ \&type $=308 \# !$ DocumentBrowse (Downloaded: 07. 07. 2018.) 
Also, as part of the reform of tax administration, Government Windows also manage 89 types of tax administration matters since early 2018. ${ }^{16}$ However, the special-duty territorial state administration organisations (that are separated from territorial administrative offices both financially and institutionally) still possess their own separate customer service centres.

Finally, it is worth mentioning that at the beginning of 2018, there were 40 legally restricted procedures in Hungary ${ }^{17}$ that could not have been initiated before the GWs (such as patent applications or postal operator matters).

Based on the summary of the responsibilities, it is apparent that from an organisational perspective, Government Windows serve as the customer service centres of the District Offices, while from a procedural law perspective, they are the primary means of submitting applications. ${ }^{18} \mathrm{GWs}$, however, handle not only cases that are assigned to DOs; sometimes they also manage tax administration matters as well.

One of the most recent developments related to GWs is the establishment of the so-called Vehicle Administration Points. These customer service points handle vehicle-related matters only, ${ }^{19}$ making it essentially a "special $G W$ ", similar in its characteristics to the advanced or county seat DOs, reinforcing the concept of differentiated task allocation.

That said, while GWs act as a fix point of customer service in state administration, they are not the only actors of territorial state administration serving in such a role. Other solutions are also in effect, which will be examined below.

\subsection{Additional means of supporting Government Windows}

To ensure that public administration services are available to the largest number of citizens, territorial state administration is utilising two additional resources besides the network of GWs: a staff of specialised Public Servants (PS) and mobile GWs. The existence of these institutions is mainly due to the fact that while the expansion of integrated customer service points remains a pivotal goal of public administration, it is impossible (and as we will see later, rationally undesirable) to open GWs in every municipality. Therefore, complementary solutions are needed to ensure that citizens who cannot visit their district seat or nearest $G W$ can also fulfil their administrative needs.

The network of the aforesaid specialised Public Servants (which keeps covering an increasingly large area of Hungary) aims to help citizens manage their administrative

16 Available: http://nav.gov.hu/nav/igazgatosagok (Downloaded: 12. 07. 2018.). Sometimes they are also called NAV Points.

17 For the exact list, see: www.kormanyhivatal.hu/download/d/e7/24000/TER-3-50-3-2018\%20KAB.pdf (Downloaded: 09. 07. 2018.)

18 Act CL of 2016 Section 37 Paragraph (1).

19 Such an office was founded in 2016 in the Ócsa GW of the Gyál DO. The next one was established in District XVIII of Budapest in 2018. 
affairs by not requiring them to leave their place of residence. Being held in the municipal buildings during opening hours, the PS assists citizens in matters handled by the DO, helps them initiating a new case, and provides support throughout the whole process of the matter. Besides these, the specialised Public Servant also assists in filling official forms and transferring those to the applicable administrative agency.

In 2017, these Public Servants provided assistance or were involved in several specific social affairs, petty offences, cases handled by GOs, family allowance and social security matters, child care and guardianship affairs, or occupational matters. The number of these DO workers and the number of settlements they cover have also greatly increased in the past years. In 2015, the network of specialised Public Servants involved 753 people serving 1,960 municipalities, while in the third quarter of 2017, their number rose to 820 , creating a network that covered 2,400 municipalities. The current aspirations of public administration development also include the continuing expansion of this network of specialised DO workers. This would mean, on the one hand, an increased number of cases and services they could handle; and on the other hand, the expansion of the network itself, with the goal to be present in 2,445 municipalities.

Another tool of ensuring proximity to citizens is the mobile government window, which is essentially a specially-equipped van, aiming to bridge the physical distances between customer service points and citizens. The mobile GW offers numerous administrative services, such as Client Gate registration or the replacement of damaged personal documents.

The vehicle is capable of serving specific GO functions, and was originally developed to provide administrative services (e.g. mass replacement of lost identity documents) on the scene of disasters. The past years, however, proved that the tool is also useful in other cases as well:

- Serving social welfare and residential care institutions, as the health conditions of the residents or nurselings may not allow them to visit their local customer service centres to extend their identity documents.

- Acting as an interim service while the local GO is rebuilt, renovated, or closed for any other reason, and therefore receives no clients.

- Establishing presence on local programmes (e.g. festivities or local celebrations).

These and similar solutions - even if remaining particular in the long run - offer insightful experiences for further developments. Their other benefit is that they provide options both for legislation and clients.

\subsection{Specialised territorial state administrative organisations in the middle level after 2016}

The administrative reform of 2016-17 brought far-reaching changes regarding the roles and scope of the central organisations, GOs, and districts. However, it also had notable effects on 
the specialised deconcentrated organisations as well. The basics of the administrative system stayed the same: the government's will was still represented through the capital and county GOs, their districts, and the specialised territorial agencies. It is worth mentioning, though, that the number of institutions in the latter group has been reduced in the past years, even if the ambitions to merge them into GOs also subsided. Instead, the emphasis was put on redefining the profiles of the specialised deconcentrated state administration agencies.

The following sub-sections provide a summary of each major specialised deconcentrated agency, in order to offer an overview of the territorial administrative organisations that exist besides capital/county GOs in Hungary at the time of finalising the manuscript of this paper.

\subsubsection{Changes in the agricultural deconcentrated state administration bodies}

Land offices, along with water protection, environment protection and nature conservation agencies, were long standing parts of Hungarian territorial state administration. Still, their numbers have been substantially reduced by now. The most recent structural transformation affected mainly two institutions:

- On 31 December 2016, the Office of Agriculture and Rural Development ceased to exist with all its territorial offices. As the organisation was also responsible for disbursing tender subsidies, the Hungarian State Treasury and its territorial bodies became its legal successors in this regard (these will be described in more detail). At the same time, the territorial offices of the Rural Development Office have been integrated into the capital and county GOs (typically as Departments of Agriculture and Rural Development).

- The other affected institution was the National Land Fund Management Organisation, whose county-level offices ceased to exist on 1 June 2017. From that date on, their special duties have been taken over by the central office of the institution.

Due to the above changes, at the time of finalising this manuscript, the National Park Directorates and the Regional Centres of the Hungarian Meteorological Service became the only remaining territorial units of the Ministry of Agriculture. The continued existence of the Directorates was justified with the fact that nature conservation duties do not necessarily align with traditional geographical jurisdictions. The regional offices of the Hungarian Meteorological Service, at the same time, were kept because they regularly perform meteorological, atmospheric physics and aeronautical meteorological surveys.

\subsubsection{The status of middle level tax and treasury administration bodies}

The tax and treasury administration bodies seemingly avoided the magnitude of corrections that affected the agricultural sector of administration. Moreover, it may seem that the two institutions of this sector, the National Tax and Customs Administration and the Hungarian 
State Treasury were resistant to the reorganisation tendencies of recent years. In reality, however, these two institutions (governed by the national economy and finances portfolio) followed their own paths of development, and have been evolving in parallel with the capital/ county GOs to this day.

The tax office has seen fundamental reforms in 2016:

- The middle-level regional tax and customs authority offices were abolished, thereby simplifying the organisation into a two-level institution.

- The tax and customs sectors were merged both in an organisational and management control sense, establishing the county-level tax and customs directorates.

- As already mentioned in the chapter on customer service centres, specific taxation matters can now be managed by Government Windows. ${ }^{20}$

The profile of the Hungarian State Treasury was also renewed. The major factor behind this change was the effort to realise potentially all state disbursements through this organisation. As part of this aspiration, the following organisational changes were conducted:

- The Treasury received the disbursement tasks of the Office of Agriculture and Rural Development.

- The Central Administration of National Pension Insurance has been merged into the Treasury on 1 November 2017.

Besides the above, the Treasury also plays an important role for common citizens, as it has the right to trade in treasury bonds, but is also strongly connected to local municipalities. The latter is due to the introduction of the municipal ASP (Advanced Service Provider), an electronic information system supporting the duties of the municipalities and their publicly financed institutions. The ASP is maintained and operated by the Government via the Treasury.

\subsubsection{Changes in the regulations concerning the territorial bodies of statistical data collection and processing}

Today's socio-economic tendencies make it essential that countries have exact figures on their resources and the processes affecting those. In Hungary, this activity is carried out by the Hungarian Central Statistical Office. The institution saw a structural transformation in 2017, during which its territorial departments (primarily responsible for data collection and regional information matters) were changed on 1 March 2017. Although there are still several local offices in operation, ${ }^{21}$ these bodies primarily operate as customer relationship points.

Gov. Decree No. 1325 of 2017 (VI. 8.).

Available: www.ksh.hu/elerhetoseg (Downloaded: 19. 07. 2018.) 


\subsubsection{The bodies of territorial state administration concerning internal affairs}

The recent changes in state administration also affected internal affairs. One of the institutions affected by these was the Office for Immigration and Citizenship, which lost its responsibilities of handling citizenship, birth/death registry and name changing matters. Thus, with a more streamlined profile, the organisation was renamed to Immigration and Asylum Office on 1 January 2017. Similarly to the earlier structure, the remaining duties are handled by seven regional directorates on a territorial level. ${ }^{22}$

The other organisation affected by recent transformations was the sphere of water conservancy directorates. These institutions belonged to the rural development portfolio until 2012, after which (primarily due to their duties in inland flood control and their relationship with disaster management) they have been transferred under the control of the Ministry of Interior. In the meantime, the water conservancy directorates have lost their legal status of being territorial state administration organisations. According to the 2016/17 regulations, they are part of the water protection management.

\subsubsection{The deconcentrated state administration funding bodies of human-public services}

The human portfolio served by the Ministry of Human Capacities handles four groups of deconcentrated bodies at the time of closing the manuscript of this study:

- The first group is the regional offices of the National Health Insurance Fund of Hungary. The specialty of these seven regional offices is that they do not act as the deconcentrated bodies of the Fund, but rather as internal units of the central organisation that are transferred to a county-level, making them essentially the county-level units of a central Fund department.

- The second group consists of the territorial offices of the National Healthcare Services Center. These offices and their legal predecessors are tasked with controlling and overseeing the professional activities of Hungarian hospitals, coordinating related projects, and investigating individual complaints.

- The third group comprises the county branches of the Directorate-General for Social Affairs and Child Protection, performing duties related to social and child protection institutions, foundations engaged in such activities, public institutions and business organisations.

- Finally, it is worth mentioning the educational sector that saw large-scale changes in 2016. The primary funding body of state education institutions, the Klebelsberg Centre for Public Education Institution Management and its system of 198 educational districts have been replaced with 59 so-called Educational District

22 Available: www.bmbah.hu/index.php?option=com_content\&view=article\&id=44\&Itemid=667\&lang=en (Downloaded: 06. 07. 2018.) 
Centres, each covering multiple districts. These District Centres are typically established in larger cities, and practice the funding and maintenance rights of public education institutions.

\subsection{Additional institutions besides deconcentrated administrative bodies on the territorial level}

Considering the fact that mid-level administrative duties are handled not just by deconcentrated state administration bodies, but also other administrative organisations, I intend to provide a short overview on them for the sake of completeness. Mid-level state administration is also supported by the following agencies:

- 19 county self-governments, whose responsibilities saw major changes in recent years. According to Act CLXXXIX of 2011 on Local Governments in Hungary and Act XXI of 1996 on Regional Development and Regional Planning, the primary responsibilities of county self-governments include regional and rural development, regional planning and the coordination of related activities. ${ }^{23}$

- Territorial units of law enforcement organisations, including:

- County police headquarters, ${ }^{24}$

- County disaster management directorates, ${ }^{25}$

- County penal institutions, ${ }^{26}$

- Territorial bodies of the Constitution Protection Office. ${ }^{27}$

- Separated from law enforcement organisations in 2018, military management also had its own administrative bodies. The Hungarian Defence Forces Military Administrative and ADP Centre operates the following types of territorial offices:

- Military Administrative Centres, ${ }^{28}$

- Recruitment and Advocacy Centres, ${ }^{29}$

- Military Administrative and Advocacy Offices. ${ }^{30}$

- Finally, it is worth mentioning that the National Media and Infocommunications Authority also has territorial organisational units. ${ }^{31}$ Due to the special legal status of the Authority, these offices are not considered deconcentrated bodies of state

${ }^{23}$ Cf. Act on Local Governments in Hungary Section 27, Paragraph (1) and Act on Regional Development and Regional Planning Sections 11-14.

24 Act XXXIV of 1994, Section 4/A, Paragraph (1).

25 Gov. Decree No. 234 of 2011. (XI. 10.), Section 3, Paragraph (1).

26 Act CVII of 1995, Section 2, Paragraph (5).

Act CXXV of 1995, Section 2, Paragraph (2).

In Budapest, Debrecen and Székesfehérvár.

In Szolnok, Szeged, Veszprém and Kaposvár.

In Kecskemét, Békéscsaba, Salgótarján, Miskolc, Eger, Nyíregyháza, Pécs, Győr, Tatabánya, Szekszárd, Szombathely and Zalaegerszeg.

31 Cf. http://nmhh.hu/dokumentum/163512/nmhh_szervezeti_abra.pdf (Downloaded 27. 07. 2018.) 
administration, but still act as parts of mid-level public administration. They include the following:

- Customer service points, ${ }^{32}$

- Local offices of the Infocommunications supervisory department. ${ }^{33}$

\section{INTERNATIONAL OUTLOOK}

This section provides a short overview on the various international tendencies and solutions related to low- and mid-level territorial state administration, serving as a means of comparison to the Hungarian solutions described in this study.

\subsection{A few words on the international trends affecting the evolution of territorial state administration}

After studying the territorial state administration system of multiple European countries, I concluded that the bodies of mid-level state administration comprise the most stable element of the public administration of countries characterised by a stable arch of development. ${ }^{34}$ However, this was not always the case. The last third of the $20^{\text {th }}$ century, for example, saw major decentralisation in many countries, which was more beneficial to municipalities than to the bodies of territorial state administration, even if the procedure was complemented by notable structural changes as well. Therefore, many functions of territorial state administration were redefined. A major trend affecting the above developments of public administration was New Public Management, ${ }^{35}$ which - starting from the 1980 s - aspired to introduce solutions to public administration that have already proved to work well in the competitive sector. ${ }^{36}$

The above tendencies eventually weakened the executive apparatus: the system of state administration and its mid-level bodies lost their official controlling authorities in several fields. This resulted in them not being able to effectively react to the financial-economic crisis, and to many other contemporary global social crises either (such as unemployment or environmental disasters). Needless to say that rapid and effective crisis management eventually required the re-evaluation of the roles that the state and public administration play in this area (as emphasised by the concept of the so-called Neo-Weberian State ${ }^{37}$ ), which encouraged the reinforcement of territorial state administration. ${ }^{38}$

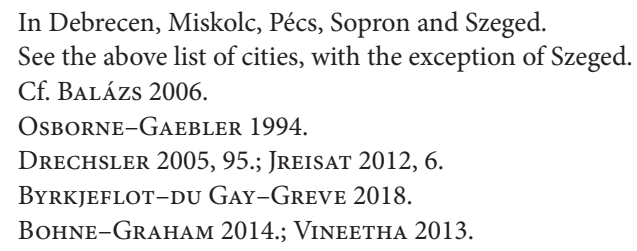




\subsection{A general overview on the tasks delegated to territorial state administration}

Based on the above, we can define the sphere of functions and responsibilities that are typically delegated to territorial state administration (but not always, and not in every country). These include, among others, the following:

- First of all, central government (power) should be represented by these organisations on the territorial level (not only in Hungary, but in other European countries too).

- Typically, deconcentrated bodies of state administration handle executive tasks that should be made independent from local conditions. These include, for example, the management of certain environmental matters that are handled by the ARPAs and APPAs (territorial environment protection agencies) in Italy. ${ }^{39}$

- The territorial bodies of state administration sometimes handle responsibilities whose organisation requires a different logic from the norm for some reason. These include, for example, the healthcare matters in Poland, tax administration and records in Finland, ${ }^{40}$ or animal welfare duties in Slovakia. ${ }^{41}$

- Certain duties specifically facilitate the control, supervision and coordination of territorial state administration bodies. A good example for this is the Representative of Central Government in Spain, whose main responsibility is the control, coordination, and supervision of regional deconcentrated organisations, ensuring that the required level of cooperation is present among them. ${ }^{42}$

- Realising the legal control ${ }^{43}$ (that is, the supervision and/orinspection) ofmunicipalities. This duty is delegated to state administration by the European Charter of Local SelfGovernment. Examples may include the related administrative bodies in Finland, ${ }^{44}$ or the County Government Commissioner in Latvia. ${ }^{45}$

- In case of crisis situations, the government's will is also realised through its deconcentrated bodies, as it can be most effective only through hierarchal control and supervision. For example, this duty is performed in France by the Prefectures, ${ }^{46}$ and in the Netherlands by the Commissioner of the King. ${ }^{47}$

39 Available: www.isprambiente.gov.it/en/national-system-for-environmental-protection/arpa-appa (Downloaded: 10. 07. 2018.)

40 OECD Territorial Reviews: Sweden 2017, 157.

41 Available: www.svps.sk/english/contacts.asp (Downloaded: 19. 07. 2018.)

42 Szamel et al. 2011, 402.

43 See Article 8 of the Charter on the administrative supervision of local authorities' activities. See also ÁrvA 2014, 177-181.

44 SzAmel et al. 2011, 583.

45 KiURIEnÉ 2015, 394-410.

46 Available: www.prefectures-regions.gouv.fr/ (Downloaded: 17. 07. 2018.)

47 OECD Territorial Reviews: Netherlands 2014, 203. 


\subsection{The major structural solutions of the system of deconcentrated organisations ${ }^{48}$}

Responsibilities assigned to mid-level state administration bodies may be carried out via two means:

- Firstly, by establishing an advanced territorial body for central administration (i.e. for the government). Typically, but not necessarily, this territorial organisation has general authority and competences. ${ }^{49}$

- Secondly, by institutionalising specialised deconcentrated state administration organisations along the various special administrative areas.

The two approaches are not mutually exclusive. On the contrary, as is the case in Hungary, most countries of the European Union employ a "mixed solution". The reason for this is that important or special responsibilities may occur anywhere that cannot be assigned to a single specialised deconcentrated territorial organisation. Moreover, even the existence of a deconcentrated group of institutions usually grants the establishment of a territorial body that coordinates the activities of said deconcentrated institutions. However, the existence of a middle-level group of specialised administrative organisations clearly marks the need of providing special services and duties. All this results in establishing the system of territorial state administration from the cooperation of multiple institutions.

Depending on the relationship among the various deconcentrated organisations, the subnational level of state administration may be either integrated or disintegrated. The first means that mid-level state administration is united in full coordination; the second refers to a divided system.

Integrated systems of territorial state administration can be established via two means. The first is operational integration, which means that the deconcentrated organisations keep their independence (in an organisational, budgetary and/or personnel sense), but - with the exception of some specific cases - they are obliged to perform their duties in accordance with a designated body of state administration. Such solutions occur in France ${ }^{50}$ and Belgium. The second approach is organisational integration, achieved by merging several organisations of territorial state administration - this approach may also complement operational integration. In such cases, mid-level state administration organisations lose their budgetary and personnel independence, along with some of their staff functions, but they still remain self-contained regarding the management of their special duties. Such solutions occur in Italy, Poland or Slovenia.

48 Available: www.eastr-asso.org/fiches-pays (Downloaded: 21. 07. 2018.). Of course, the division shown on this page is not exclusive. Such country groups can be created along other considerations as well. For example, see LOPIŽIČ-NovAK 2018, 291-295.

49 There are exceptions to this rule, though. For example, no such organisation exists in the Czech Republic. Available: https://is.mendelu.cz/eknihovna/opory/zobraz_cast.pl?cast=62458 (Downloaded: 21. 07. 2018.)

50 For additional useful details, see EyMERI-DOUZANS - BOUCKAERT 2013. 
European countries whose territorial state administration is divided are considered to be disintegrated both in an organisational and operational sense. Such countries include, for example, Portugal. ${ }^{51}$

\section{CONCLUSIONS}

The study is concluded with a summary of its key conclusions, based on the Hungarian and international phenomena currently in effect.

Since 2010, one of the most fundamental efforts of the Hungarian governing parties was to reinforce the role of the government by finding a remedy to the existing problems of the executive branch (such as overlaps in the list of responsibilities, unnecessary operational parallelisms, or an overly divided organisational structure in some aspects), and within it, of the issues of territorial state administration in particular. ${ }^{52}$ To achieve this, legislation made an intensive effort to raise governmental capacity. Based on the entirety of this endeavour, I conclude that the government followed the path of concentration and integration, and aimed to delegate duties and authorities to state administration, in general. In parallel to this, it also created a more integrated executive apparatus in the middle level of state administration.

Due to the fractured nature of the professional impact studies, preparatory materials and model tests, it is difficult to ascertain whether such complex interventions are successful, effective and sustainable. ${ }^{53}$ Still, several elements exist that have been part of the task rationalisation and administrative reorganisation efforts for a period of eight years (at the time of closing the manuscript of this paper), and which are, therefore, worth emphasising. Thus, the general and specialised bodies of deconcentrated state administration saw the following major changes in this interval:

- As part of the organisational integration, the number of organisations continuously decreased.

- As part of the operational integration, the responsibilities and authorities of the GOs and their leaders continuously increased.

- By establishing DOs, the lower section of mid-level public administration became more uniformed.

- Customer service activities saw a renewal on the territorial level.

51 For more information on the earlier system, see OECD Territorial Reviews: Portugal 2008, 24. Additionally, regarding the operation of the deconcentrated bodies following the re-assignment of the district governors' responsibilities, see: https://en.wikipedia.org/wiki/Districts_of_Portugal (Downloaded: 02. 07. 2018.)

52 See Gov. Decree No. 62 of 2012 (IV. 2.) on announcing the public administration development frame agreement between the Government of Hungary and the OECD.

53 Regarding these, see the Good State Reports, and the evaluation material of the OECD on the Public Administration and Public Service Development Strategy. The former is available here: https://akfi.uni-nke.hu/joallam-jelentes (Downloaded: 01. 07. 2018.) The latter is accessible here: https://read.oecd-ilibrary.org/governance/hungary-2017_9789264286535-en\#page1 (Downloaded: 12. 07. 2018.) 
Therefore, the Hungarian government tries to manage the same amount of duties with a smaller number of deconcentrated organisations. This aspiration is summarised in the Public Administration and Public Service Development Strategy, based on the theoretical framework of the Magyary Programme. The administrative reform of this Strategy is based on two pillars:

- grant a controlling and strategy-making role to the central level of administration, and

- let the bodies of territorial state administration handle official matters and maintain their institutions.

As such, legislation managed to overwrite the previously significant amount of sectorial self-interest. By adhering to an administrative development process that borrowed several Neo-Weberian elements, the government surpassed almost all former reform attempts in eliminating unwarranted structural divisions and unnecessary parallelisms. The general direction of these efforts was organisational integration. ${ }^{54}$ However, it should not be forgotten that such a more coordinated, close-knit operation can still be challenged, and that sectorial separatism may still regain its strength, if the coordination-supervision rights of the GOs are not used (for example, in case of co-operational obligations, reorganisations, promotions or discharges). In addition - as I already mentioned - the non-integrated special-duty deconcentrated organisations are not the sole mid-level institutions of state administration. Other organisations also exist (like territorial law enforcement units, municipalities and other institutions of special legal status) with whom communication should be established and maintained.

One of the very important advantages of the GOs is that with their presence, the specialised administrative fields that were organically related, but otherwise formerly separated from each other, have been finally integrated to the same institution (in accordance with the real-life management of those fields). By establishing the GOs, legislation gained territorial organisations which are capable of receiving administrative duties that cannot be delegated to any other specialised territorial body of any portfolio. In addition, by establishing the system of GOs and DOs, a new way has opened to perform the on-demand vertical re-assignment of responsibilities, as was the case at the end of 2016 and early 2017. Related to this, it is also worth mentioning that with the GOs and DOs, legislation is performing a differentiated assignment of tasks and authorities, which is expected to continue in the long run.

However, the fusion of tasks and authorities, and the structural reforms were not performed just for their own sake; they were initiated to improve client satisfaction. The establishment of the GWs, the creation of the specialised DO workers network, and the expansion/enhancement of the available e-administration services all aim to improve

54 See the data on page 24 of Magyary Program 2011. (Available: https://infoter.hu/attachment/0011/10551_ magyary_program.pdf) and the revised version of 2012. 
customer proximity, and to make public administration matters easier to perform. However, there is still room for improvement.

Generally speaking, the goal of territorial state administration is to convey the government's will to a lower level. Because of this, and also due to recent global trends, it must operate in an integrated fashion. At the same time, my international outlook proves that there is no standard to follow when organising mid-level state administration - instead, governments typically combine the means of organisational and operational integration. Just take the solutions of the Polish, ${ }^{55}$ Slovenian ${ }^{56}$ or Finnish ${ }^{57}$ territorial state administrations as examples. These countries rely on territorial government offices that are similar in nature to the Hungarian GOs; however, there are several special administrative branches that are still represented with their own separate organisations in the middle-level of public administration. This is mostly due to the fact that special state administration duties must be provided in as many locations in the country as possible. Albeit further developments in e-administration may surpass physical constraints in this field, such developments take time to mature.

Based on the assessment above, it is clear that deconcentrated state administration organisations will play a great role in handling the notable socio-economic challenges of our times and the near future. This sphere of administrative bodies plays a pivotal role in increasing government competitiveness, and reinforcing communication among the various levels of the government. The Hungarian aspirations of public administration development carved a clear path which leads toward a territorial state administration system that is more integrated in its duties, organisation and personnel as well. In the end, the goal is clear: the deconcentrated administrative bodies must be able to contribute to the concept of a new, more effective state. ${ }^{58}$

For example, see www.poznan.uw.gov.pl/en (Downloaded: 09. 07. 2018.)

Available: www.upravneenote.gov.si/ (Downloaded: 20. 07. 2018.)

Available: www.avi.fi/en/web/avi-en/frontpage\#.WrMOuWrOWvE (Downloaded: 20. 07. 2018.)

Bouckaert-NaKrošis-Nemec 2011, 9-29. 


\section{REFERENCES}

1. Árva Zsuzsanna (2014): A közigazgatás quasi bíráskodási tevékenysége. Debrecen, Debreceni Egyetemi Kiadó. DOI: https://doi.org/10.24169/djm/2019/3-4/4

2. BALÁzs István (2006): A központi szint alatti közigazgatás egyes EU-tagállamokban. In LőRINCz Lajos ed.: Közigazgatás az Európai Unió tagállamaiban. Budapest, Unió.

3. BARta Attila (2012): New Trends in the Territorial Representation of Governments. Curentul Juridic, Vol. 10, No. 1 (48). 75-84. Available online at: http://revcurentjur.ro/ old/arhiva/attachments_201201/recjurid121_6F.pdf (Downloaded: 21. 07. 2018.)

4. BARTA Attila (2017): The Next Generation of Capital and County Government Offices. Developments in Hungarian Middle-Level State Administration since 2011. In SzIKorA Veronika - ÁrvA Zsuzsanna eds.: Jogtudomány a jogfejlödés szolgálatában. Szemelvények a modern jogi kutatások köréből. Debrecen, Debreceni Egyetem Állam- és Jogtudományi Kar. 27-42. Available electronically at: https:// dea.lib.unideb.hu/dea/bitstream/handle/2437/243273/FILE_UP_0_BartaAttila. pdf? sequence $=1 \&$ isAllowed $=y$ (Downloaded: 13. 07. 2018.)

5. Bohne, Eberhard - Graham, John D. eds. (2014): Public administration and the modern state. Assessing trends and impact. Houndmills, Basingstoke, Hampshire; New York, Palgrave Macmillan.

6. Bouckaert, Geert - Nakrošis, Vitalis - Nemec, Juraj (2011): Public Administration and Management Reforms in CEE: Main Trajectories and Results. NISPAcee Journal of Public Administration and Policy, Vol. 4, No. 1. 9-29. DOI: https://doi.org/10.2478/ v10110-011-0001-9

7. Byrkjeflot, Haldor - du Gay, Paul - Greve, Carsten (2018): What is the 'NeoWeberian State' as a Regime of Public Administration? In Ongaro, Edoardo - VAN Thiel, Sandra eds.: The Palgrave Handbook of Public Administration and Management in Europe. London, Palgrave Macmillan. 991-1009. DOI: https://doi.org/10.1057/9781-137-55269-3_50

8. Drechsler, Wolfgang (2005): The Reemergence of "Weberian" Public Administration after the Fall of New Public Management: The Central and Eastern European Perspective. Halduskultuur, Vol. 6. 94-108.

9. Eymeri-Douzans, Jean-Michel - Bouckaert, Geert (2013): La France et ses administrations. Un état des savoirs. France and its public administrations. A state of the art. Bruxelles, Bruylant.

10. Jreisat, Jamil (2012): Globalism and Comparative Public Administration. Boca Raton (FL), CRC Press. DOI: https://doi.org/10.1201/b11088

11. HoRváth M. Tamás (2016): Az ágazati közszolgáltatások rendszertanáról. In HoRvátH M. Tamás - BARTHA Ildikó eds.: Közszolgáltatások megszervezése és politikái. Budapest, Dialóg Campus. 25-37.

12. KIURIEnÉ, Violeta (2015): Administrative supervision of local self-government in the Baltic states: a comparative view. Journal of Education Culture and Society, Vol. 6, No. 2. 394-410. DOI: https://doi.org/10.15503/jecs20152.394.410 
13. LopIžIč, Iva - Novak, Goranka Lalić (2018): The Role of Deconcentrated State Administration in Migration and Integration Affairs: A Way Forward. Croatian and Comparative Public Administration, Vol. 18, No. 2. 287-312. https://doi.org/10.31297/ hkju.18.2.2

14. Osborne, David - GAebler, Ted (1994): Új utak a közigazgatásban (Vállalkozó szellem a közösségi szektorban). Budapest, Kossuth Könyvkiadó.

15. Patyi András - Rixer Ádám eds. (2014): Hungarian Public Administration and Administrative Law. Passau, Schenk Verlag. 304-319. Available electronically at: http://m.ludita.uni-nke.hu/repozitorium/bitstream/handle/11410/7798/patyi_andras. pdf? sequence $=1 \&$ isAllowed $=y$ (Downloaded: 09. 07. 2018.)

16. Szamel Katalin - Balázs István - Gajduschek György - Koi Gyula eds. (2011): Az Európai Unió tagállamainak közigazgatása. Budapest, Complex.

17. Veszprémi Bernadett (2015): Az információs társadalom kihívásai és a közigazgatás reakciói. Debrecen, Debreceni Egyetemi Kiadó.

18. Vineetha, Menon (2013): Administrative Organization. New Delhi, Wisdom Press.

\section{Online documents}

1. OECD Territorial Reviews: Netherlands 2014. DOI: http://dx.doi.org/10.1787/97892 64209527-en

2. OECD Territorial Reviews: Portugal 2008. www.oecd.org/gov/oecdterritorialreviewsportugal.htm (Downloaded: 03. 07. 2020.)

3. OECD Territorial Reviews: Sweden 2017. DOI: http://dx.doi.org/10.1787/978926 4268883-en

Dr. Attila Barta PhD has been working for the Faculty of Law at the University of Debrecen since 2009. He started teaching subjects as a lecturer at the Department of Administrative Law, and currently serves as assistant professor of said department. His main research topics include mid-level public administration, territorial state administration, the system of self-governments, and public procedural law. In 2012, he was appointed as Rapporteur of Applications and Innovation for the Faculty of Law. He has received a PhD in 2013 and published his first book entitled Hungarian Territorial State Administration. Since 2016, he serves as Rapporteur for Strategic Planning and External Relations. He is a member of the General Assembly of the Hungarian Academy of Sciences since 2014. Besides his academic work and research, he is also constantly involved in the training and examination of public servants. 